\title{
Yield and Chemical Composition of Brussels Sprout (Brassica oleracea L. gemmifera) as Affected by Boron Management
}

Metin Turan', Nizamettin Ataoglu, Adem Gunes, and Taskin Oztas

Atatürk University, Faculty of Agriculture, Department of Soil Science, 25240 Erzurum, Turkey

Atilla Dursun and Melek Ekinci

Atatürk University, Agriculture Faculty, Department of Horticulture, TR-25240 Erzurum, Turkey

\section{Quirine M. Ketterings}

Cornell University, College of Agriculture and Life Sciences, Department of Animal Science, Ithaca, NY 14853

\section{Yuh Ming Huang}

National Chung Hsing University, Department of Soil and Environmental Science, 250 Kuokuang Road, Taichung, Taiwan, R.O.C.

Additional index words. Ardisol, boron, Brussels sprout, macro- and micronutrient, optimum economic yield

\begin{abstract}
Boron (B) deficiency is widespread in the Anatolia region of Turkey. This could impact production and quality of Brussels sprout (Brassica oleracea $\mathrm{L}$. gemmifera). A 2year field experiment was conducted to study yield and quality response of four cultivars (Star, Brilliant, Oliver, and Maximus) to $B$ addition $\left(0,1,3\right.$, and $\left.9 \mathrm{~kg} \cdot \mathrm{ha}^{-1} \mathrm{~B}\right)$. The optimum economic B rate (OEBR) ranged from 5.5 to $6.3 \mathrm{~kg} \cdot \mathrm{ha}^{-1} \mathrm{~B}$ resulting in soil $B$ levels of 0.94 to $1.13 \mathrm{mg} \cdot \mathrm{kg}^{-1}$. Independent of cultivar, $B$ application decreased tissue nitrogen, calcium, and magnesium but increased tissue phosphorus, potassium, iron, manganese, zinc, and copper content. We conclude a $B$ addition of $6 \mathrm{~kg} \cdot \mathrm{ha}^{-1}$ is sufficient to elevate soil $B$ levels to nondeficient levels. Similar studies with different soils and initial soil test $B$ levels are needed to conclude if these critical soil test values and OEBR can be applied across the region.
\end{abstract}

Vegetable production continues to increase worldwide and Turkey is the fourth largest producer with 25.3 million tones annually (Anonymous, 2005). In terms of economic value, nutrition, consumer preference, general adaptability, and extent of cultivation, the most commonly grown vegetable crops in Turkey are tomato (Lycopersicon esculentum L.), watermelon [Citrillus lanatus (Thunb.) Mansf.], cucumber (Cucumis sativus L.), pepper (Capsicum annuum L.), eggplant (Solanum melongena L. var. esculentum Nees), squashes (Cucurbita pepo L., C. maxima L., and C. moschata L.), onion (Allium cepa L.), snap bean (Phaseolus vulgaris L.), melon (Cucumis melo L.), radish (Raphanus sativus L.), and salad vegetables, including lettuce (Lactuca sativa L. var.

Received for publication 25 Aug. 2008. Accepted for publication 1 Nov. 2008.

We are very grateful to National Boron Research Institute of Turkey for their generous financial support for this study (Project Number AR-GE/8). ${ }^{1}$ To whom reprint requests should be addressed; e-mail m_turan25@hotmail.com.
2006; Kacar and Fox, 1967; Kacar et al., 1979).

Boron management is challenging because the optimum B application range is narrow (Gupta, 1993), and optimum B application rates can differ from one soil to another (Gupta, 1993; Marschner, 1995).

Crop response to B application has been documented for wheat (Triticum durum Desf.) (Soylu et al., 2004), sunflower (Helianthus annuus L.) (Asad et al., 2002; Oyinlola, 2007), and chickpea (Cicer arietinum L.) (Ceyhan et al., 2007). However, little is known about the $B$ requirements of Brussels sprout.

The objectives of this study were 1) to evaluate the yield response of four cultivars of Brussels sprout to B fertilizer; 2) to determine the effects of $\mathrm{B}$ addition on the mineral composition of Brussels sprout heads; and 3) to determine optimum soil test B levels for Brussels sprout cultivars under field conditions.

\section{Materials and Methods}

Background information for the study site. This study was conducted at the Agricultural Research Station of Ataturk University located in Erzurum, Turkey (long. $39^{\circ} 55^{\prime} \mathrm{N}$, lat. $\left.41^{\circ} 16^{\prime} \mathrm{E}\right)$ during the summer periods (late May to late September) of 2005 and 2006 . Its altitude is $1835 \mathrm{~m}$. The soil was classified as an Aridisol with parent materials mostly consisting of volcanic, marn, and lacustrin transported material (Soil Survey Staff, 1992). The experimental region has a semiarid climate. During the growing period, the mean maximum temperature was $29^{\circ} \mathrm{C}$ in both years, whereas the minimum temperature was $10^{\circ} \mathrm{C}$ in 2005 and $13{ }^{\circ} \mathrm{C}$ in 2006 . The mean relative humidity, wind speed, daily sunshine, total precipitation, and total evaporation amounted to $54.58 \%, 2.72 \mathrm{~m} \cdot \mathrm{s}^{-1}$, $11.23 \mathrm{~h}, 63.4 \mathrm{~mm}$, and $388.7 \mathrm{~mm}$ in 2005 (20 May to $29 \mathrm{Sept}$.), and $57.95 \%, 3.50 \mathrm{~m} \cdot \mathrm{s}^{-1}$, $10.07 \mathrm{~h}, 48.9 \mathrm{~mm}$, and $448 \mathrm{~mm}$ in 2006 (28 May to 10 Oct.), respectively.

Before seedling, soil samples were taken over two depths ( 0 to 30 and 30 to $60 \mathrm{~cm}, 20$ subsamples) to determine baseline soil properties. Soil samples were air-dried, crushed, and passed through a 2-mm sieve before chemical analysis. Cation exchange capacity was determined using sodium acetate (buffered at $\mathrm{pH}$ 8.2) and ammonium acetate (buffered at $\mathrm{pH}$ 7.0) according to Sumner and Miller (1996). The Kjeldahl method (Bremner, 1996) was used to determine total nitrogen $(\mathrm{N})$, whereas plant-available phosphorus $(\mathrm{P})$ was determined by using the sodium bicarbonate method of Olsen et al. (1954). Electrical conductivity (EC) was measured in saturation extracts according to Rhoades (1996). Soil $\mathrm{pH}$ was determined in 1:2 extracts, and calcium carbonate concentrations were determined according to McLean (1982). Soil organic matter was determined using the Smith-Weldon method according to Nelson and Sommers (1982). Ammonium acetate buffered at $\mathrm{pH} 7$ (Thomas, 

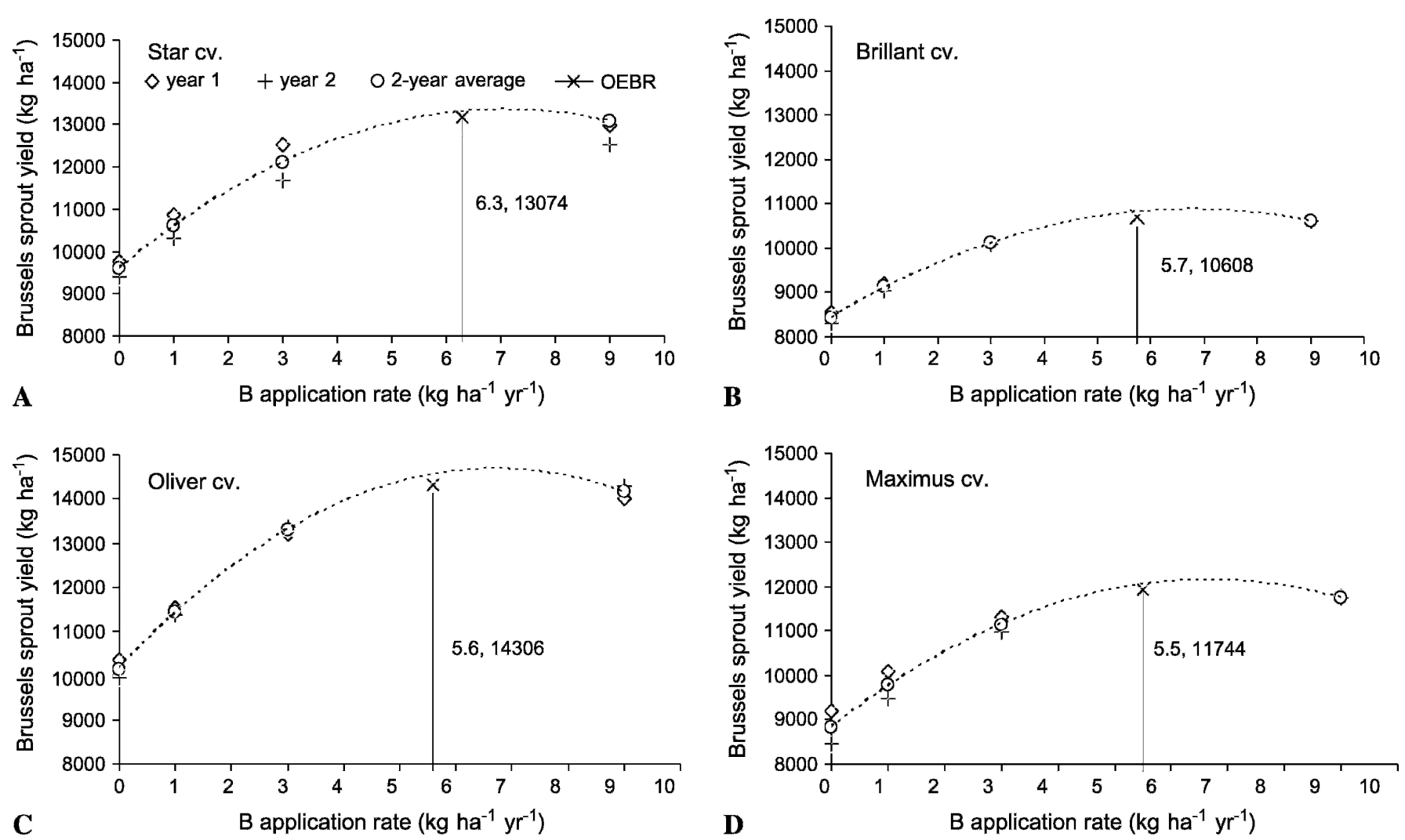

Fig. 1. Brussels sprout cultivar yields as affected by boron (B) applications (2-year average) to a B-deficient calcareous Aridisol in eastern Turkey. Identified are optimum economic B rates for each of the 2 years and the 2-year average assuming U.S. $\$ 0.65 \mathrm{~kg}^{-1} \mathrm{~B}$ and a Brussels sprout value of U.S. $\$ 2.08 \mathrm{~kg}{ }^{-1}$.

Table 1. Chemical properties of the experimental field soils before seedling (mean $\pm \mathrm{sD}, \mathrm{n}=20$ ).

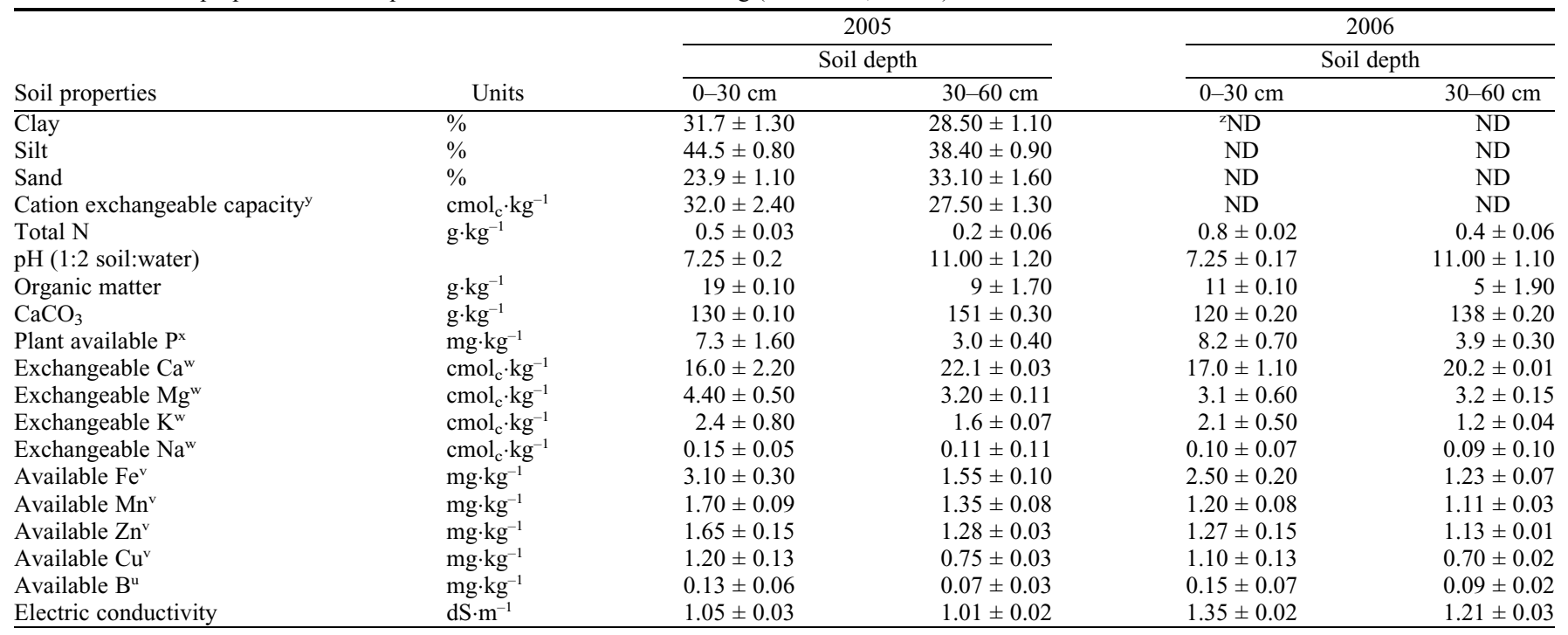

\section{${ }^{\mathrm{z}} \mathrm{ND}=$ not done.}

${ }^{\mathrm{y}}$ Sodium acetate at $\mathrm{pH} 8.2$ according to Sumner and Miller (1996).

${ }^{\mathrm{x}}$ Sodium bicarbonate according to Olsen et al. (1954).

${ }^{\mathrm{w}}$ Ammonium acetate at $\mathrm{pH} 7.0$ according to Thomas (1982).

'Diethylene triamine pentaacetic acid extraction according to Lindsay and Norvell (1978).

"Azomethine-H extraction according to Wolf (1974).

1982) was used to determine exchangeable cations. Microelements in the soils were determined by diethylene triamine pentaacetic acid extraction methods (Lindsay and Norvell, 1978). Some physical and chemical properties of soil were given in Table 1.

Trial design. The experiment was laid out in a split plot design with four Brussels sprout cultivars (Star, Brilliant, Oliver, and Maximus) as the main plot and four B application levels $\left(0,1,3\right.$, and $\left.9 \mathrm{~kg} \cdot \mathrm{ha}^{-1} \mathrm{~B}\right)$ as the subplot in four replicates. Individual plots $(3 \times 3 \mathrm{~m})$ consisted of raised beds $(3.0 \mathrm{~m}$ long and $3.0 \mathrm{~m}$ wide). A $2.0-\mathrm{m}$ space was left between the plots to prevent water movement from one plot to another. Twenty-four Brussels sprout plants were planted in each plot on 24 May 2005 and 1 June 2006. Row distance was $70 \mathrm{~cm}$ and plants were spaced $40 \mathrm{~cm}$ apart within rows.

Plant cultivation and fertility management. Before planting, N, P, potassium (K), and B were broadcast-applied in each plot at the rates of $350 \mathrm{~N} \mathrm{~kg} \cdot \mathrm{ha}^{-1}$ (as ammonium sulfate), $92 \mathrm{~kg} \cdot \mathrm{ha}^{-1} \mathrm{P}$ (as triple superphosphate), 166 
Table 2. Yields, optimum economic boron (B) rates (assuming U.S. $\$ 0.65 \mathrm{~kg}^{-1} \mathrm{~B}$ and a Brussels sprout value of U.S. $\$ 2.08 \mathrm{~kg}^{-1}$ ), and $R^{2}$ of the quadratic fit for the yield response data for Brussels sprout cultivars grown on a calcareous Aridisol in eastern Turkey in 2005 and 2006.

\begin{tabular}{|c|c|c|c|c|c|c|c|c|}
\hline \multirow[b]{3}{*}{ Year } & \multirow{3}{*}{$\begin{array}{c}\text { Brussels } \\
\text { sprout } \\
\text { cultivar }\end{array}$} & \multicolumn{4}{|c|}{$\mathrm{B}$ application rate } & \multirow[b]{3}{*}{ OEBR } & \multirow{3}{*}{$\begin{array}{c}\text { Yield } \\
\text { at OEBR }\end{array}$} & \multirow[b]{3}{*}{$R^{2}$} \\
\hline & & 0 & 1 & 3 & 9 & & & \\
\hline & & \multicolumn{4}{|c|}{$\mathrm{kg} \cdot \mathrm{ha}^{-1}$} & & & \\
\hline \multirow[t]{4}{*}{$\overline{2005}$} & Oliver & $10,113 \mathrm{~d}$ & $11,924 \mathrm{c}$ & $13,024 \mathrm{a}$ & $12,754 \mathrm{~b}$ & 5.7 & 14,010 & 0.953 \\
\hline & Star & $9,484 \mathrm{~d}$ & $11,361 \mathrm{c}$ & $12,317 \mathrm{~b}$ & $13,000 \mathrm{a}$ & 6.4 & 13,617 & 0.918 \\
\hline & Maximus & $9,292 \mathrm{~d}$ & $9,896 \mathrm{c}$ & $11,382 \mathrm{a}$ & $10,373 \mathrm{~b}$ & 5.2 & 11,761 & 0.977 \\
\hline & Brilliant & $8,627 \mathrm{c}$ & $9,092 \mathrm{~b}$ & $10,173 \mathrm{a}$ & $9,982 \mathrm{a}$ & 5.8 & 10,601 & 0.988 \\
\hline \multirow[t]{4}{*}{2006} & Oliver & $9,547 \mathrm{~d}$ & $12,062 \mathrm{c}$ & $13,067 \mathrm{a}$ & $12,693 \mathrm{~b}$ & 5.6 & 14,302 & 0.902 \\
\hline & Star & $9,036 \mathrm{~d}$ & $10,942 \mathrm{c}$ & $11,404 \mathrm{~b}$ & $11,964 \mathrm{a}$ & 6.3 & 12,351 & 0.876 \\
\hline & Maximus & $8,409 \mathrm{c}$ & $9,556 \mathrm{~b}$ & $10,942 \mathrm{a}$ & $10,756 \mathrm{a}$ & 5.8 & 11,744 & 0.998 \\
\hline & Brilliant & $8,114 \mathrm{c}$ & $9,360 \mathrm{~b}$ & $9,957 \mathrm{a}$ & $9,840 \mathrm{a}$ & 5.7 & 10,614 & 0.927 \\
\hline \multirow[t]{4}{*}{ Average } & Oliver & $9,830 \mathrm{~d}$ & $11,993 \mathrm{c}$ & $13,045 \mathrm{a}$ & $12,724 \mathrm{~b}$ & 5.6 & 14,156 & 0.927 \\
\hline & Star & $9,260 \mathrm{~d}$ & $11,152 \mathrm{c}$ & $11,860 \mathrm{~b}$ & $12,482 \mathrm{a}$ & 6.3 & 13,074 & 0.919 \\
\hline & Maximus & $8,850 \mathrm{~d}$ & $9,726 \mathrm{c}$ & $11,162 \mathrm{a}$ & $10,564 \mathrm{~b}$ & 5.5 & 11,744 & 0.998 \\
\hline & Brilliant & $8,370 \mathrm{c}$ & $9,226 \mathrm{~b}$ & $10,065 \mathrm{a}$ & $9,911 \mathrm{a}$ & 5.7 & 10,608 & 0.990 \\
\hline
\end{tabular}

OEBR $=$ optimum economic $\mathrm{B}$ rate.

Different letters within the rows indicate mean differences at $P<0.05$ significance level.

$\mathrm{kg} \cdot \mathrm{ha}^{-1} \mathrm{~K}$ (as potassium sulfate), and $0,1,3$, and $9 \mathrm{~kg} \cdot \mathrm{ha}^{-1} \mathrm{~B}$ (as $\mathrm{Na}_{2} \mathrm{~B}_{4} \mathrm{O}_{7} \cdot 10 \mathrm{H}_{2} \mathrm{O}$ ), respectively (Booij, 2000; Turan and Sevimli, 2005). The crop was weeded manually with a hoe and weeding was repeated as required. No pesticide was applied.

Irrigation water applications. Good-quality underground water with an EC of $0.28 \mathrm{dS} \cdot \mathrm{m}^{-1}$, sodium adsorption ratio of 0.40 , and $\mathrm{pH}$ of 7.4 was used for surface irrigation. The moisture content ( 0 - to $60-\mathrm{cm}$ soil depth) was increased to field capacity after planting and soil moisture contents at $0-$ to $30-\mathrm{cm}$ and $30-$ to $60-\mathrm{cm}$ soil depths were determined daily by time domain reflectometer (TDR 300; Spectrum Technologies, East Plainfield, IL). When the moisture content fell below $23.5 \%(\mathrm{Pw})$, a total of 32.4 $\mathrm{mm}$ irrigation water was applied to the soil based on an effective root depth of $60 \mathrm{~cm}$ (Allen et al., 1998). The total amount of irrigation water was $388.8 \mathrm{~mm}$ in 2005 and $453.6 \mathrm{~mm}$ in 2006.

Soil boron and plant sampling and analytical methods. Three soil samples from each plot were taken from 0 to $30 \mathrm{~cm}$ when Brussels sprouts started heading. The samples were air-dried, crushed, and passed through a 2-mm sieve before B analysis using the azomethine-H extraction as described in Wolf (1974) and an Aqumat ultraviolet/VIS spectrophotometer (Thermo Electron Spectroscopy Ltd., Cambridge, U.K.).
Of the 24 plants per plot, eight plants were sampled at heading time to determine the mineral contents of the heads, whereas another eight plants were harvested on 28 Sept. 2005 and 6 Oct. 2006 to determine season yields. Three heads per plant were taken at heading time for a total of 24 heads per treatment. Samples were oven-dried at $68{ }^{\circ} \mathrm{C}$ for $48 \mathrm{~h}$ and ground to pass $1 \mathrm{~mm}$. The Kjeldahl method and a Vapodest 10 Rapid Kjeldahl Distillation Unit (Gerhardt, Konigswinter, Germany) were used to determine total N (Bremner, 1996). Macro- [P, K, calcium $(\mathrm{Ca})$, and magnesium $(\mathrm{Mg})]$ and microelements [iron (Fe), manganese $(\mathrm{Mn})$, zinc $(\mathrm{Zn})$, and copper $(\mathrm{Cu})]$ were determined after wet digestion of dried and ground subsamples using a $\mathrm{H}_{2} \mathrm{SO}_{4}-\mathrm{HClO}_{4}$ acid mixture $(4: 1 \mathrm{v} / \mathrm{v})$ (AOAC922.02 2005; Mertens, 2005a). Phosphorus in the extraction solution was measured spectrophotometrically using the indophenol-blue and ascorbic acid method (AOAC931.01 2005; Mertens, 2005b) and an Aqumat ultraviolet/VIS spectrophotometer (Thermo Electron Spectroscopy Ltd.). Tissue $\mathrm{K}, \mathrm{Ca}$, and $\mathrm{Mg}, \mathrm{Fe}, \mathrm{Mn}, \mathrm{Zn}$, and $\mathrm{Cu}$ were determined after wet digestion using a $\mathrm{H}_{2} \mathrm{SO}_{4}-\mathrm{HClO}_{4}$ acid mixture $(4: 1 \mathrm{v} / \mathrm{v})$ and a Perkin-Elmer 360 atomic absorption spectrophotometer (Perkin-Elmer, Waltham, MA) (AOAC975.03 2005; Mertens, 2005c). Boron analysis was done using the azomethine-H procedure and an Aqumat ultraviolet/VIS spectrophotometer (Thermo Electron Spectroscopy Ltd.) (AOAC958.03 2005; Mertens, 2005d).
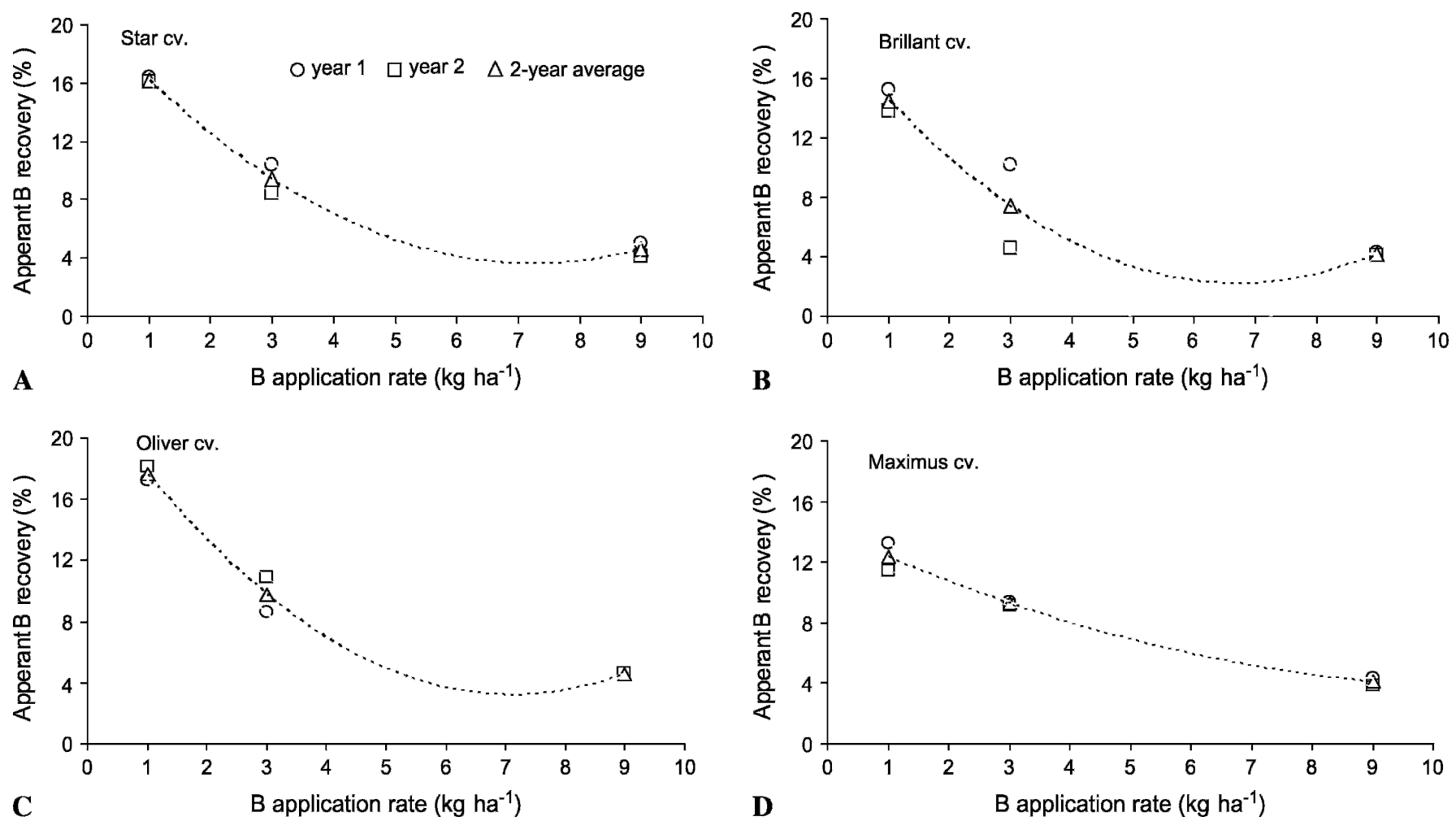

Fig. 2. Relationship between boron (B) application and apparent B recovery for four Brussels sprout cultivars grown on a calcareous Aridisol in eastern Turkey. At the economic optimum B rates of 5.6, 6.3, 5.5, and $5.7 \mathrm{~kg} \cdot$ ha $^{-1} \cdot \mathrm{year}^{-1} \mathrm{~B}$ (averaged over the 2 years) for 'Oliver', 'Star', 'Maximus', and 'Brilliant', the apparent B recovery was $4 \%, 4 \%, 6 \%$, and $23 \%$, respectively. 

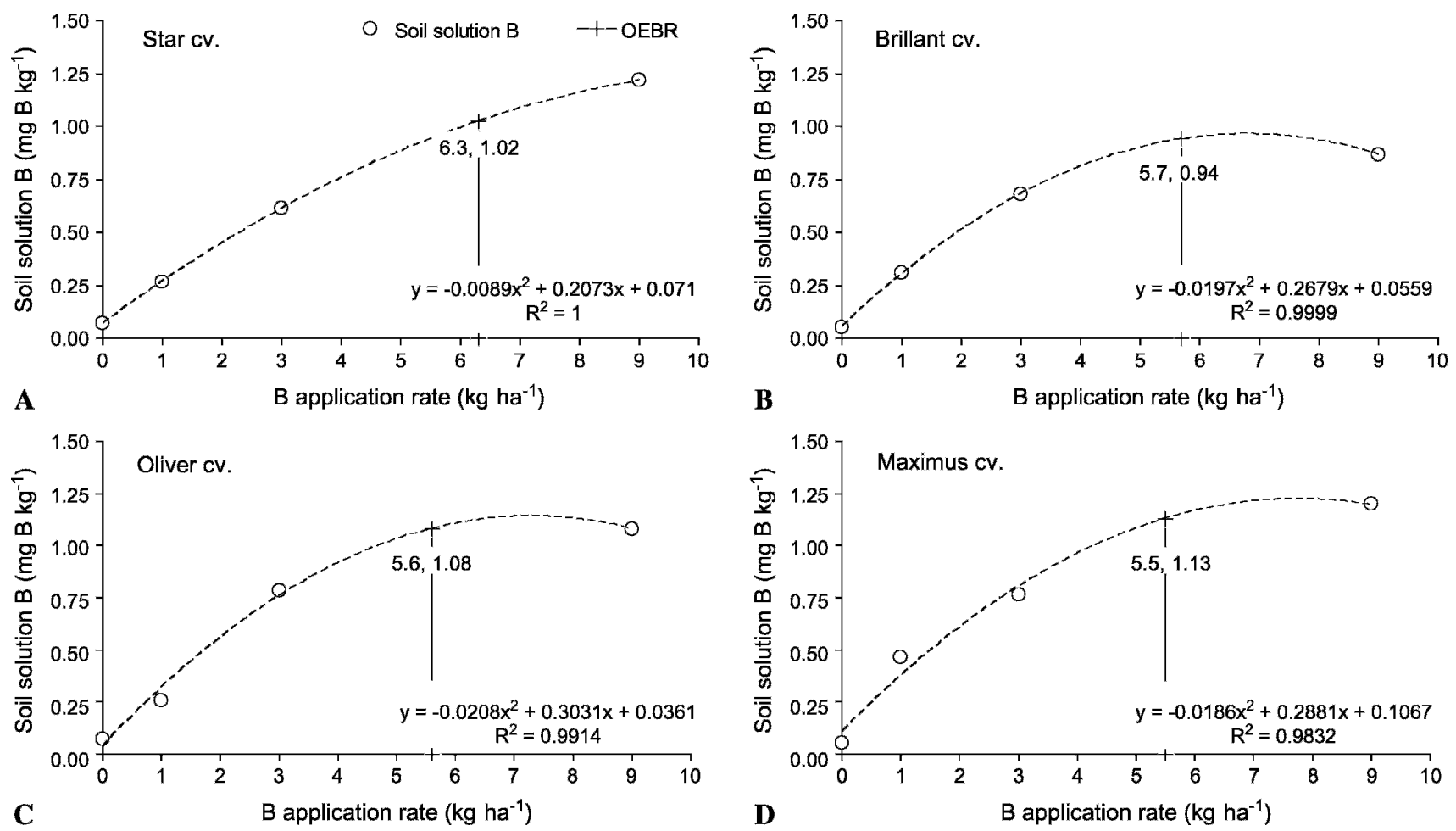

Fig. 3. Relationship between boron (B) application and soil solution B concentration (2-year average) for four Brussels sprouts cultivars (Star, Brilliant, Oliver, and Maximus) grown on a calcareous Aridisol in eastern Turkey. At the optimum economic B rate (OEBR), soil solution B ranged from 0.94 to $1.13 \mathrm{mg} \cdot \mathrm{kg}^{-1} \mathrm{~B}$.

Table 3. Leaf macroelement concentration of Brussels sprout cultivars when grown in 2 consecutive years under four different boron (B) application treatments on a calcareous Aridisol in eastern Turkey in 2005 and 2006

\begin{tabular}{|c|c|c|c|c|}
\hline \multirow{3}{*}{$\begin{array}{l}\text { B application doses } \\
\mathrm{kg} \cdot \mathrm{ha}^{-1}\end{array}$} & \multicolumn{4}{|c|}{ Brussels sprout cultivars } \\
\hline & Oliver & Star & Maximus & Brillian \\
\hline & \multicolumn{4}{|c|}{$\Longrightarrow$ of dry matter- } \\
\hline & \multicolumn{4}{|c|}{$\mathrm{N}$} \\
\hline 0 & $2.47 \mathrm{a}$ & $2.32 \mathrm{~b}$ & $2.28 \mathrm{a}$ & $2.31 \mathrm{a}$ \\
\hline 1 & $2.46 \mathrm{a}$ & $2.44 \mathrm{a}$ & $2.09 \mathrm{~b}$ & $2.22 \mathrm{a}$ \\
\hline 3 & $2.35 \mathrm{~b}$ & $2.34 \mathrm{~b}$ & $1.99 \mathrm{c}$ & $2.09 \mathrm{~b}$ \\
\hline 9 & $2.22 \mathrm{c}$ & $2.20 \mathrm{c}$ & $1.85 \mathrm{~d}$ & $1.88 \mathrm{c}$ \\
\hline Adjusted $R^{2}$ & 0.683 & 0.711 & 0.767 & 0.631 \\
\hline \multirow[t]{2}{*}{ LSD } & 0.050 & 0.033 & 0.050 & 0.058 \\
\hline & $0.67 \mathrm{c}$ & $0.70 \mathrm{~d}$ & $0.62 \mathrm{~d}$ & $0.65 \mathrm{~d}$ \\
\hline 1 & $0.77 \mathrm{~b}$ & $0.97 \mathrm{c}$ & $0.81 \mathrm{c}$ & $0.74 \mathrm{c}$ \\
\hline 3 & $0.87 \mathrm{a}$ & $1.14 \mathrm{~b}$ & $0.86 \mathrm{~b}$ & $0.81 \mathrm{~b}$ \\
\hline 9 & $0.83 \mathrm{a}$ & $1.28 \mathrm{a}$ & $0.89 \mathrm{a}$ & $0.88 \mathrm{a}$ \\
\hline Adjusted $R^{2}$ & 0.670 & 0.841 & 0.920 & 0.907 \\
\hline \multirow[t]{2}{*}{ LSD } & 0.025 & 0.049 & 0.015 & 0.013 \\
\hline & \multicolumn{4}{|c|}{$\mathrm{Ca}$} \\
\hline 0 & $3.92 \mathrm{a}$ & $3.95 \mathrm{a}$ & $4.05 \mathrm{a}$ & $4.03 \mathrm{a}$ \\
\hline 1 & $3.58 \mathrm{~b}$ & $3.73 \mathrm{~b}$ & $3.52 \mathrm{~b}$ & $3.77 \mathrm{~b}$ \\
\hline 3 & $3.27 \mathrm{c}$ & $3.62 \mathrm{~b}$ & $3.43 \mathrm{~b}$ & $3.42 \mathrm{~b}$ \\
\hline 9 & $2.57 \mathrm{~d}$ & $3.27 \mathrm{c}$ & $3.17 \mathrm{c}$ & $3.23 \mathrm{c}$ \\
\hline Adjusted $R^{2}$ & 0.902 & 0.635 & 0.897 & 0.696 \\
\hline \multirow[t]{2}{*}{ LSD } & \multirow{2}{*}{\multicolumn{4}{|c|}{0.091}} \\
\hline & & & & \\
\hline 0 & $1.32 \mathrm{~d}$ & $1.19 \mathrm{~d}$ & $1.53 \mathrm{c}$ & $1.63 \mathrm{~d}$ \\
\hline 1 & $1.63 \mathrm{c}$ & $1.28 \mathrm{c}$ & $1.78 \mathrm{~b}$ & $1.82 \mathrm{c}$ \\
\hline 3 & $1.93 \mathrm{~b}$ & $1.83 \mathrm{~b}$ & $2.02 \mathrm{a}$ & $1.97 \mathrm{~b}$ \\
\hline 9 & $2.08 \mathrm{a}$ & $1.93 \mathrm{a}$ & $2.13 \mathrm{a}$ & $2.08 \mathrm{a}$ \\
\hline Adjusted $R^{2}$ & 0.841 & 0.964 & 0.894 & 0.977 \\
\hline \multirow[t]{2}{*}{ LSD } & 0.064 & 0.031 & 0.062 & 0.033 \\
\hline & \multicolumn{4}{|c|}{$\mathrm{Mg}$} \\
\hline 0 & $2.27 \mathrm{c}$ & $2.47 \mathrm{a}$ & $2.32 \mathrm{a}$ & $2.11 \mathrm{a}$ \\
\hline 1 & $2.73 \mathrm{a}$ & $2.48 \mathrm{a}$ & $2.12 \mathrm{~b}$ & $1.75 \mathrm{~b}$ \\
\hline 3 & $2.28 \mathrm{~b}$ & $2.28 \mathrm{~b}$ & $1.97 \mathrm{~b}$ & $2.03 \mathrm{a}$ \\
\hline 9 & $2.47 \mathrm{c}$ & $1.85 \mathrm{c}$ & $1.76 \mathrm{c}$ & $1.79 \mathrm{~b}$ \\
\hline Adjusted $R^{2}$ & 0.829 & 0.761 & 0.670 & 0.410 \\
\hline LSD & 0.085 & 0.071 & 0.079 & 0.075 \\
\hline
\end{tabular}

LSD $=$ least significant difference.

Different letters within the columns indicate mean differences at $P<0.05$ significance level.
Statistical analysis. The experiment was laid out in a split plot design with four Brussels sprout cultivars (Star, Brilliant, Oliver, and Maximus) in a randomized block design as main plots and four B application levels $\left(0,1,3\right.$, and $\left.9 \mathrm{~kg} \cdot \mathrm{ha}^{-1} \mathrm{~B}\right)$ as the subplot in four replicates. All data were subjected to analysis of variance and significant means were compared by Duncan's multiple range test method performed using SPSS 13.0 (SPSS Inc., 2004). Mean differences were considered significant if $P \leq 0.05$. The optimum economic B rate (OEBR) was defined as the $B$ rate at which the highest returns to $\mathrm{B}$ fertilizer were obtained assuming a quadratic-plus-plateau model, a Brussels sprout value of U.S. $\$ 2.08 \mathrm{~kg}^{-1}$, and a fertilizer cost of U.S. $\$ 0.65 \mathrm{~kg}^{-1}$ B. For return per ha calculations, an annual (fixed) cost of production of $\$ 833.53 / \mathrm{ha}^{-1}$ was assumed. For each B application rate, the apparent B recovery $(\mathrm{ABR})$ was calculated as the $\mathrm{B}$ removal in harvest per kilogram $B$ applied:

Apparent $\mathrm{B}$ recovery $(\%)=\left(\mathrm{B}\right.$ at $\mathrm{B}_{\text {rate }}-\mathrm{B}$

$$
\text { at control }) /(\mathrm{B} \text { applied }) * 100
$$

\section{Results}

Boron fertilizer application affected the yield of all Brussels sprout cultivars in each of the 2 years and there were no statistically significant differences between the mean yields of the 2 years (Fig. 1). There were no significant interactions between cultivar selection and B treatment for any of the response variables. The highest yields were obtained with the Oliver cv. (Table 2) 
Table 4. Leaf microelement concentration of Brussels sprout cultivars when grown in 2 consecutive years under four different boron (B) application treatments on a calcareous Aridisol in eastern Turkey in 2005 and 2006.

\begin{tabular}{|c|c|c|c|c|}
\hline \multirow{3}{*}{$\begin{array}{l}\text { B application doses } \\
\mathrm{kg} \cdot \mathrm{ha}^{-1}\end{array}$} & \multicolumn{4}{|c|}{ Brussels sprout cultivars } \\
\hline & Oliver & Star & Maximus & Brilliant \\
\hline & \multicolumn{4}{|c|}{$\mathrm{mg} \cdot \mathrm{kg}^{-1}$ dry matter } \\
\hline & \multicolumn{4}{|c|}{$\mathrm{Fe}$} \\
\hline 0 & $10.50 \mathrm{~d}$ & $9.67 \mathrm{~d}$ & $8.83 \mathrm{c}$ & $7.33 \mathrm{~d}$ \\
\hline 1 & $16.67 \mathrm{c}$ & $15.83 \mathrm{c}$ & $13.33 \mathrm{~b}$ & $10.83 \mathrm{c}$ \\
\hline 3 & $29.17 \mathrm{~b}$ & $25.50 \mathrm{~b}$ & $18.83 \mathrm{a}$ & $18.50 \mathrm{~b}$ \\
\hline 9 & $37.33 \mathrm{a}$ & $30.17 \mathrm{a}$ & $20.17 \mathrm{a}$ & $21.33 \mathrm{a}$ \\
\hline Adjusted $R^{2}$ & 0.986 & 0.985 & 0.910 & 0.971 \\
\hline \multirow[t]{2}{*}{ LSD } & 0.607 & 0.476 & 0.678 & 0.465 \\
\hline & \multicolumn{4}{|c|}{$\mathrm{Zn}$} \\
\hline 0 & $26.50 \mathrm{c}$ & $23.83 \mathrm{c}$ & $20.33 \mathrm{~d}$ & $17.50 \mathrm{~d}$ \\
\hline 1 & $30.50 \mathrm{~b}$ & $30.50 \mathrm{~b}$ & $23.17 \mathrm{c}$ & $21.17 \mathrm{c}$ \\
\hline 3 & $33.00 \mathrm{a}$ & $34.50 \mathrm{a}$ & $26.17 \mathrm{~b}$ & $31.17 \mathrm{~b}$ \\
\hline 9 & $34.33 \mathrm{a}$ & $33.67 \mathrm{a}$ & $31.50 \mathrm{a}$ & $38.83 \mathrm{a}$ \\
\hline Adjusted $R^{2}$ & 0.819 & 0.914 & 0.917 & 0.976 \\
\hline \multirow[t]{2}{*}{ LSD } & 0.688 & 0.685 & 0.615 & 0.638 \\
\hline & \multicolumn{4}{|c|}{$\mathrm{Mn}$} \\
\hline 0 & $10.00 \mathrm{c}$ & $9.83 \mathrm{c}$ & $10.67 \mathrm{~d}$ & $11.33 \mathrm{c}$ \\
\hline 1 & $14.83 \mathrm{~b}$ & $16.67 \mathrm{~b}$ & $12.00 \mathrm{c}$ & $13.50 \mathrm{~b}$ \\
\hline 3 & $19.33 \mathrm{a}$ & $17.17 \mathrm{~b}$ & $13.83 \mathrm{~b}$ & $16.67 \mathrm{a}$ \\
\hline 9 & $19.83 \mathrm{a}$ & $19.50 \mathrm{a}$ & $15.17 \mathrm{a}$ & $16.67 \mathrm{a}$ \\
\hline Adjusted $R^{2}$ & 0.945 & 0.929 & 0.803 & 0.846 \\
\hline \multirow[t]{2}{*}{ LSD } & 0.465 & 0.478 & 0.581 & 0.456 \\
\hline & \multicolumn{4}{|c|}{$\mathrm{Cu}$} \\
\hline 0 & $7.00 \mathrm{~d}$ & $7.83 \mathrm{~b}$ & $5.00 \mathrm{c}$ & $6.50 \mathrm{c}$ \\
\hline 1 & $10.00 \mathrm{c}$ & $11.33 \mathrm{a}$ & $4.50 \mathrm{c}$ & $9.83 \mathrm{~b}$ \\
\hline 3 & $12.17 \mathrm{a}$ & $11.50 \mathrm{a}$ & $6.33 \mathrm{~b}$ & $9.67 \mathrm{~b}$ \\
\hline 9 & $11.33 \mathrm{~b}$ & $10.83 \mathrm{a}$ & $8.33 \mathrm{a}$ & $10.83 \mathrm{a}$ \\
\hline Adjusted $R^{2}$ & 0.935 & 0.706 & 0.823 & 0.922 \\
\hline \multirow[t]{2}{*}{ LSD } & 0.281 & 0.473 & 0.333 & 0.252 \\
\hline & \multicolumn{4}{|c|}{ B } \\
\hline 0 & $6.62 \mathrm{~d}$ & $6.90 \mathrm{~d}$ & $7.38 \mathrm{~d}$ & $7.54 \mathrm{~d}$ \\
\hline 1 & $24.29 \mathrm{c}$ & $23.11 \mathrm{c}$ & $19.70 \mathrm{c}$ & $22.06 \mathrm{c}$ \\
\hline 3 & $35.88 \mathrm{~b}$ & $35.18 \mathrm{~b}$ & $35.21 \mathrm{~b}$ & $29.75 b$ \\
\hline 9 & $47.84 \mathrm{a}$ & $48.07 \mathrm{a}$ & $44.27 \mathrm{a}$ & $45.06 \mathrm{a}$ \\
\hline Adjusted $R^{2}$ & 0.991 & 0.994 & 0.986 & 0.994 \\
\hline LSD & 0.701 & 0.578 & 0.814 & 0.512 \\
\hline
\end{tabular}

LSD $=$ least significant difference.

Different letters within the columns indicate mean differences at $P<0.05$ significance level. at OEBRs that ranged from $5.5 \mathrm{~kg} \cdot \mathrm{ha}^{-1} \mathrm{~B}$ to $6.3 \mathrm{~kg} \cdot \mathrm{ha}^{-1} \mathrm{~B}$ (Table 2).

Boron application reduced the $\mathrm{ABR}$ (Fig. 2). The ABR at the OEBR varied from $\approx 4 \%$ for Oliver and Star to slightly more than $6 \%$ for Maximus and almost $23 \%$ for Brilliant (Fig. 2).

Without $\mathrm{B}$ addition, the average (2-year) soil B contents at heading time were 0.072 , $0.072,0.055$, and $0.053 \mathrm{mg} \cdot \mathrm{kg}^{-1}$ for Oliver, Star, Maximus, and Brilliant cultivars, respectively. This increased to $1.08,1.02,1.13$, and $0.94 \mathrm{mg} \cdot \mathrm{kg}^{-1}$ B for 'Oliver', 'Star', 'Maximus', and 'Brilliant', respectively, when B fertilizer was applied at the OEBR (Fig. 3).

Boron fertilizer application decreased tissue $\mathrm{N}, \mathrm{Ca}$, and $\mathrm{Mg}$ and increased $\mathrm{P}, \mathrm{K}$, $\mathrm{Fe}, \mathrm{Zn}, \mathrm{Mn}$, and $\mathrm{Cu}$ content of all four cultivars (Tables 3 and 4). The 2-year average tissue $\mathrm{B}$ content in the control treatments was $6.62,6.90,7.38$, and $7.35 \mathrm{mg} \cdot \mathrm{kg}^{-1}$ dry weight for 'Oliver', 'Star', 'Maximus', and 'Brilliant', respectively. This increased to 49.7, 50.2, 46.8, and $42.5 \mathrm{mg} \cdot \mathrm{kg}^{-1} \mathrm{~B}$, respectively, when $\mathrm{B}$ fertilizer was applied at the OEBR (Figure 4).

\section{Discussion}

The OEBRs in our study were higher than the 1.5 to $4.4 \mathrm{~kg} \cdot \mathrm{ha}^{-1} \mathrm{~B}$ rates obtained for mustard [Brassica juncea (L.)] by Stangoulis et al. (2000) and for bentgrass (Agrostis palustris Huds.) by Guertal (2004) but lower than the $8.0 \mathrm{~kg} \cdot \mathrm{ha}^{-1} \mathrm{~B}$ obtained for sunflower by Oyinlola (2007). Oyinlola (2007) emphasized that the high OEBR might be related to low initial soil B level in the study (0.09 $\mathrm{mg} \cdot \mathrm{kg}^{-1}$ as compared with 0.13 to $0.15 \mathrm{mg} \cdot \mathrm{kg}^{-1}$ in our study). The higher OEBR
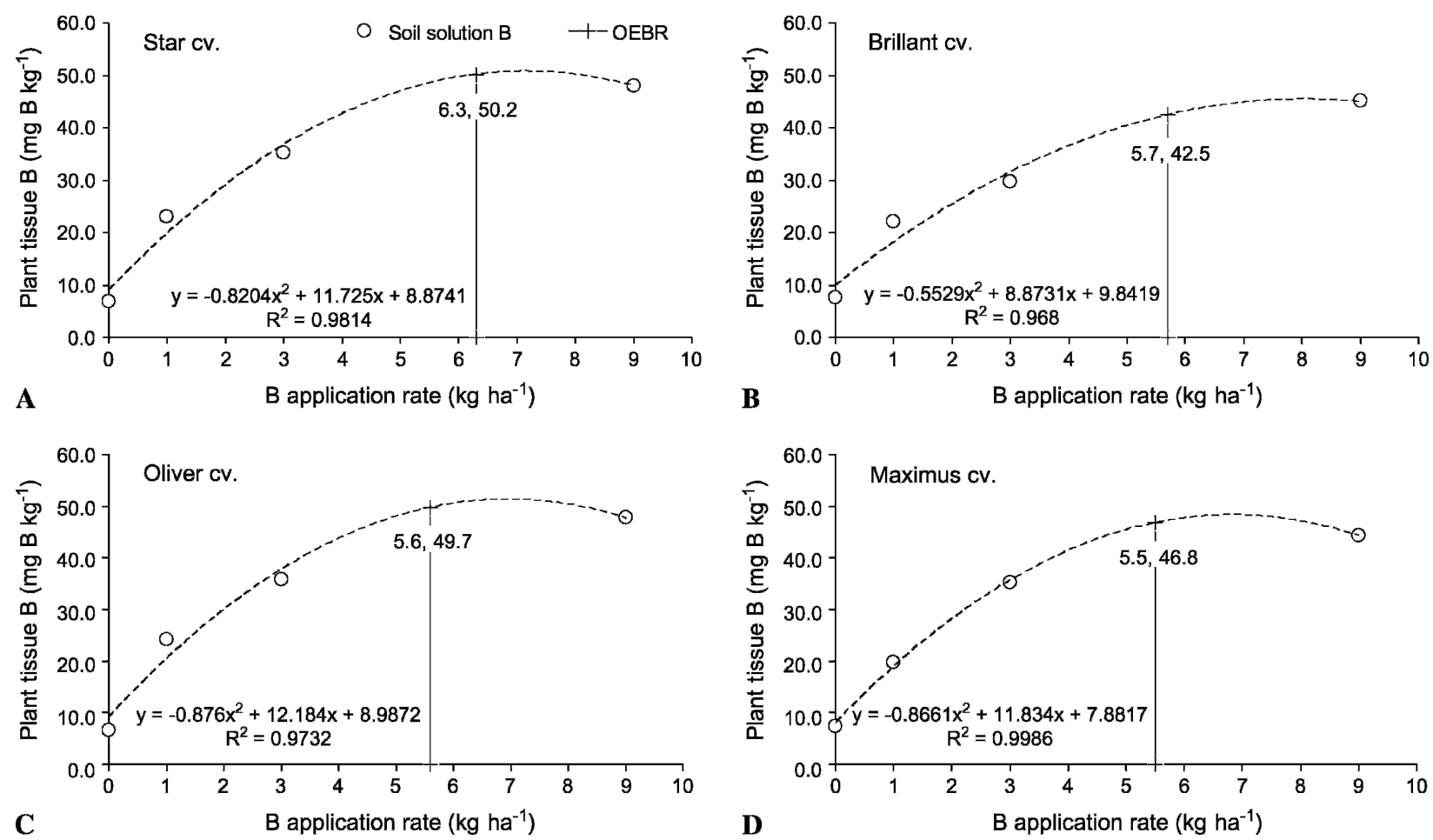

Fig. 4. Relationship between boron (B) application and Brussels sprout tissue B content (2-year average) for four Brussels sprouts cultivars (Star, Brilliant, Oliver, and Maximus) grown on a calcareous Aridisol in eastern Turkey. At the optimum economic B rate (OEBR), plant tissue B ranged from 42.5 to $50.2 \mathrm{mg} \cdot \mathrm{kg}^{-1} \mathrm{~B}$. 
may also be related to soil type (Alfisol) and sunflower sensitivity to B deficiency (Tisdale et al., 1985).

The ABRs in our study were higher than those obtained by Byju et al. (2007) for sweetpotato, in which the highest ABR was $0.4 \%$ at a $\mathrm{B}$ application rate of $1.0 \mathrm{~kg} \cdot \mathrm{ha}^{-1}$, but lower than those obtained by Santos et al. (2004) for alfalfa in which the ABR decreased from $48 \%$ on application of 0.25 $\mathrm{kg} \cdot \mathrm{ha}^{-1} \mathrm{~B}$ to $10 \%$ when $2.0 \mathrm{~kg} \cdot \mathrm{ha}^{-1} \mathrm{~B}$ was applied. These differences most likely reflect the very low initial soil B concentration $\left(0.025 \mathrm{mg} \cdot \mathrm{kg}^{-1} \mathrm{~B}\right)$ in the study by Santos et al. (2004).

Soil B content at the optimum yield in our study was higher than the $0.28 \mathrm{mg} \cdot \mathrm{kg}^{-1} \mathrm{~B}$ reported by Asad et al. (1997) for canola (Brassica napus L.) grown under greenhouse conditions. On the other hand, our study showed lower optimum soil B levels than the $2 \mathrm{mg} \cdot \mathrm{kg}^{-1}$ reported for muskmelon ( $\mathrm{Cucu}$ mis melo L.) grown in field conditions (Goldberg et al., 2003), possibly reflecting speciesspecific differences in optimum soil B content as well as soil and greenhouse to field differences.

Compiling results from the greenhouse and field experiments published during 10 years, Guertal (2004), Santos et al. (2004), and Ross et al. (2006) suggested $10 \mathrm{mg} \cdot \mathrm{kg}^{-1}$, $66 \mathrm{mg} \cdot \mathrm{kg}^{-1}, 44.1 \mathrm{mg} \cdot \mathrm{kg}^{-1}$ in plant tissue to be the critical level for boron in bentgrass (Agrostis palustris Huds.), alfalfa (Medicago sativa cv. Crioula), and soybean [Glycine $\max$ (Merr.) L.], respectively. The range in tissue $\mathrm{B}$ content at the OEBR in our study (42.5 to $50.2 \mathrm{mg} \cdot \mathrm{kg}^{-1}$ B) suggests similar critical tissue B contents for Brussels sprouts as for soybeans.

The concentrations of all plant nutrients measured were within agronomic critical levels defined in Mills and Jones (1996) except for $\mathrm{N}, \mathrm{Fe}$, and Mn. Mills and Jones (1996) defined critical ranges of $3.10 \%$ to $4.50 \%$ for $\mathrm{N}, 60$ to $150 \mathrm{mg} \cdot \mathrm{kg}^{-1}$ for $\mathrm{Fe}$, and 25 to $200 \mathrm{mg} \cdot \mathrm{kg}^{-1}$ for $\mathrm{Mn}$, suggesting N, Fe, and Mn addition might increase yields beyond those obtained in our study.

\section{Conclusion}

Boron application increased Brussels sprout yield, indicating $\mathrm{B}$ deficiency. Averaged over the 2 years, the maximum return to $\mathrm{B}$ fertilizer was obtained for the Oliver cv. at an OEBR of $5.6 \mathrm{~kg} \cdot \mathrm{ha}^{-1}$ B. Tissue $B$ content increased from $6.62 \mathrm{mg} \cdot \mathrm{kg}^{-1}$ dry weight in the control treatment to $37.81 \mathrm{mg} \cdot \mathrm{kg}^{-1} \mathrm{~B}$ when $\mathrm{B}$ was applied at the OEBR. Across all cultivars, soil B levels ranged from 0.94 to $1.13 \mathrm{mg} \cdot \mathrm{kg}^{-1}$ at OEBRs that ranged from 5.5 to $6.3 \mathrm{~kg} \cdot \mathrm{ha}^{-1}$ B. Independent of cultivar, B application increased tissue $\mathrm{P}, \mathrm{K}, \mathrm{Fe}, \mathrm{Mn}, \mathrm{Zn}$, and $\mathrm{Cu}$ content but decreased tissue $\mathrm{N}, \mathrm{Ca}$, and $\mathrm{Mg}$ for each of the cultivars. We conclude $\mathrm{B}$ addition of $6 \mathrm{~kg} \cdot \mathrm{ha}^{-1}$ is sufficient to elevate soil B levels of this soil with an initial B content of $0.13 \mathrm{mg} \cdot \mathrm{kg}^{-1}$ to nondeficient levels of 0.94 to $1.13 \mathrm{mg} \cdot \mathrm{kg}^{-1}$. Similar studies with different soils and initial soil test $\mathrm{B}$ levels are needed to conclude if these B application rates and critical soil test values can be applied across the region.

\section{Literature Cited}

Allen, R.G., L.S. Pereira, D. Raes, and M. Smith. 1998. Crop evapotranspiration: Guidelines for computing crop water requirements. FAO Irrigation and Drainage Paper No. 56. FAO, Rome, Italy.

Anantawiroon, P., K.D. Subedi, and B. Rerkasem. 1997. Screening wheat for for boron efficiency, p. 101-104. In: Bell R.W. and B. Rerkasem (eds.). Boron in soil and plants. Proceedings. Kluwer Academic Publishers, Dordrecht, The Netherlands.

Angin, I., M. Turan, Q.M. Ketterings, and A. Cakıc1. 2008. Humic acid addition enhances $\mathrm{B}$ and $\mathrm{Pb}$ phytoextraction by Vetiver grass [Vetiveria zizanioides (L.) Nash]. Water Air Soil Pollut. 188:335-343.

Anonymous. 2005. FAO, Statistical database. Aug. 2008. <http://www.fao.org $>$.

Asad, A., R.W. Bell, B. Dell, and L. Huang. 1997. External boron requirements for canola (Brassica nopus L.) in boron buffered solution culture. Ann. Bot. (Lond.) 80:65-73.

Asad, A., F.P.C. Blamey, and D.G. Edwards. 2002. Dry matter production and boron concentrations of vegetative and reproductive tissues of canola and sunflower plants grown in nutrient solution. Plant Soil 243:243-252.

Booij, R. 2000. Effects of nitrogen on yield components of Brussels sprouts (Brassica oleracea L. var. gemmifera DC). European Journal of Horticultural Science 65:30-34.

Bremner, J.M. 1996. Nitrogen-total, p. 1085-1121. In: Bartels, J.M. and J.M. Bigham (eds.). Methods of soil analysis. Part 3: Chemical methods. The Soil Science Society of America and the American Society of Agronomy, Madison, WI.

Byju, G., M. Nedunchez hiyan, and S.K. Naskar. 2007. Sweet potato response to boron application on an Alfisols in the sub humid tropical climate of India. Commun. Soil Sci. Plant Anal. 38:2347-2356.

Ceyhan, E., M. Önder, M. Harmankaya, M. Hamurcu, and S. Gezgin. 2007. Response of chickpea cultivars to application of boron in boron-deficient calcareous soils. Commun. Soil Sci. Plant Anal. 38:2381-2399.

Gezgin, S., N. Dursun, M. Hamurcu, and Y. Ayasli. 1999. Konya ovasında şekerpancarı bitkisinin beslenme sorunlarının toprak ve bitki analizleri ile belirlenmesi. Konya Pancar Ekicileri Kooperatifi Eğitim ve Sağlık Vakfi Yayınlari.

Gezgin, S., N. Dursun, M. Hamurcu, M. Harmankaya, M. Önder, B. Sade, A. Topal, S. Soylu, N. Akgün, M. Yorgancilar, E. Ceyhan, N. Çiftçi, B. Acar, I. Gültekin, Y. Işik, C. Ş;eker, and M. Babaoğlu. 2002. Determination of boron contents of soils in central Anatolian cultivated lands and its relations between soil and water characteristics, p. 391-400. In: H.E. Goldbach, B. Rerkasem, M.A. Wimmer, P.H. Brown, M. Thellier, and R.W. Bell (eds.). Boron in plant and animal nutrition. Kluwer Academic/Plenum Publishers, New York, NY.

Gezgin, S. and M. Hamurcu. 2006. The importance of the nutrient elements interaction and the interactions between boron with the other nutrients elements in plant nutrition. Selçuk Universitesi, Ziraat Fakülktesi, Dergisi, p. 2431.
Goldberg, S., P.J. Shouse, S.M. Lesch, C.M Grieve, J.A. Poss, H.S. Forster, and D.L. Suarez. 2003. Effect of high boron application on boron content and growth of melons. Plant Soil 256:403-411.

Guertal, E.A. 2004. Boron fertilization of bentgrass. Crop Sci. 44:204-208.

Gupta, U.C. 1993. Factors affecting boron uptake by plants, p. 87-104. In: Gupta, U.C. (ed.). Boron and its role in crop production. CRC Press Inc., Boca Raton, FL.

Kacar, B. and R.L. Fox. 1967. Boron status of some Turkish soils. University of Ankara, Yearbook of the Faculty of Agriculture, p. 9-11.

Kacar, B., E. Prezeemek, A. Özgümüş, C. Turan, A.V. Katkat, and İ. Kayıkçıŏlu. 1979. Türkiye'de çay tarımı yapılan toprakların ve çay bitkisinin mikroelement gereksinimleri üzerinde bir araştırma. S.1-67, TÜBITTAK, Tarım ve Ormancilık Araştırma Grubu, Kesin Rapor Proje No. 321 Ankara.

Lindsay, W.L. and W.A. Norvell. 1978. Development of a DTPA soil test for zinc, iron, manganese and copper. Soil Sci. Soc. Amer. J. 42:421428.

Marschner, H. 1995. Mineral nutrition of higher plants. Academic Press, San Diego, CA.

Mertens, D. 2005a. AOAC Official Method 922.02. Plants Preparation of Laboratuary Sample. Official Methods of Analysis. 18th Ed. In: Horwitz, W. and G.W. Latimer (eds.). Chapter 3, p. 1-2, AOAC-International Suite 500, 481. North Frederick Avenue, Gaitherburg, MD.

Mertens, D. 2005b. AOAC Official Method 931.01. Phosphorus in Plants. Official Methods of Analysis. 18th Ed. In: Horwitz, W. and G.W. Latimer (eds.). Chapter 3, p. 21-22, AOACInternational Suite 500, 481. North Frederick Avenue, Gaitherburg, MD.

Mertens, D. 2005c. AOAC Official Method 975.03. Metal in Plants and Pet Foods. Official Methods of Analysis. 18th Ed. In: Horwitz, W. and G.W. Latimer (eds.). Chapter 3, p. 3-4, AOACInternational Suite 500, 481. North Frederick Avenue, Gaitherburg, MD.

Mertens, D. 2005d. AOAC Official Method 958.03. Boron in Plants. Official Methods of Analysis. 18th Ed. In: Horwitz, W. and G.W. Latimer (eds.). Chapter 3, p. 13-14, AOACInternational Suite 500, 481. North Frederick Avenue, Gaitherburg, MD.

McLean, E.O. 1982. Soil $\mathrm{pH}$ and lime requirement, p. 199-224. In: Page, A.L., R.H. Miller and D.R. Keeney (eds.). Methods of soil analysis. Part II. Chemical and microbiological properties. 2nd Ed. ASA SSSA Publisher Agronomy. No. 9, Madison, WI.

Mills, H.A. and J.B. Jones. 1996. Plant analysis handbook II. Micromacro Publishing, Athens, GA.

Nelson, D.W. and L.E. Sommers. 1982. Organic matter, p. 574-579. In: Page, A.L., R.H. Miller and D.R. Keeney (eds.). Methods of soil analysis. Part II. Chemical and microbiological properties. 2nd Ed. ASA SSSA Publisher Agronomy. No. 9, Madison, WI.

Olsen, S.R., C.V. Cole, F.S. Watanabe, and L.A. Dean. 1954. Estimation of available phosphorus in soils by extraction with sodium bicarbonate. USDA, Circ 939, Washington, DC.

Oyinlola, E.Y. 2007. Effect of boron fertilizer on yield and oil content of three sunflower cultivars in the Nigerian Savanna. Journal of Agronomy 6:421-426.

Rhoades, J.D. 1996. Salinity: Electrical conductivity and total dissolved solids, p. 417-436. In: Bartels, J.M. and J.M. Bigham (eds.). Methods 
of soil analysis. Part III. Chemical methods. 2nd Ed. ASA SSSA Publisher Agronomy. No. 5, Madison, WI.

Ross, J.R., N.A. Slaton, K.R. Brye, and R.E. Delong. 2006. Boron fertilization influence on soybean yield and leaf and seed boron concentrations. Agron. J. 98:198-205.

Santos, A.R., W.T. Matttos, A.S. Almeida, F.A Monteiro, B.D. Correa, and U.C. Gupta. 2004. Boron nutrition and yield of alfalfa cultivar Crioula in relation to boron supply. Scientia Agricola 61:496-500.

Shorrocks, V.M. 1997. The occurrence and correction of boron deficiency. Plant Soil 193:121-148.

Soil Survey Staff. 1992. Keys to soil taxonomy. 5th Ed. SMSS Technical monograph. No. 19. Blacksburg Pocahontas Press Inc., Blacksburg, VA.
Soylu, S., A. Topal, B. Sade, A. Akgun, S. Gezgin, and M. Babaoglu. 2004. Yield and yield attributes as affected by boron application in boron deficient calcareous soils. An evaluation of major Turkish genotypes for boron efficiency. J. Plant Nutr. 27:1077-1106.

SPSS Inc. 2004. SPSS Inc. SPSS ${ }^{\circledR} 13.0$ base user's guide. Prentice Hall, Chicago, IL.

Stangoulis, J.C.R., S.G. Harsharn, W.B. Richard, and D.G. Robin. 2000. Boron efficiency in oilseed rape: I. Genotypic variation demonstrated in field and pot grown Brassica napus $\mathrm{L}$. and Brassica juncea L. Plant Soil 225:243-251.

Sumner, M.E. and W.P. Miller. 1996. Cation exchange capacity and exchange coefficients, p. 1201-1230. In: Bartels, J.M. and J.M. Bigham (eds.). Methods of soil analysis. Part III.
Chemical methods. 2nd Ed. ASA SSSA Publisher Agronomy. No. 5. Madison, WI.

Thomas, G.W. 1982. Exchangable cations, p. 159165. Chemical and microbiological properties. Agronomy Monograph No. 9. 2nd Ed. ASA SSSA, Madison, WI.

Tisdale, S.L., W.L. Nelson, and J.J. Beaton. 1985. Soil fertility and fertilizers. 4th Ed. MacMillan Publ. Co., New York, NY.

Turan, M. and F. Sevimli. 2005. Influence of different nitrogen sources and levels on ion content of cabbage (Brassica oleracea var. capitate). N. Z. J. Crop Hort. Sci. 33:241249.

Wolf, B. 1974. Improvements in the azomethine$\mathrm{H}$ method for the determining of boron. Commun. Soil Sci. Plant Anal. 5:39-44. 